ISSN:1991-8178
EISSN: $2309-8414$
DOI: $10.22587 /$ ajbas.2017.11.15.9
Journal home page: www.ajbasweb.com

\title{
The Scars of the Industrial Landscape of the City of Kenadsa
}

\author{
${ }^{1}$ Ratiba Wided BIARA $*{ }^{2}$ Adil MOSTADI, ${ }^{3}$ Sara Imane BIARA \\ 1 Responsible of Department of architecture, Faculty of technology, ARCHIPEL Laboratory, University Tahri Mohamed Bechar, Algeria \\ ${ }^{2}$ Department of architecture, Faculty of technology, ARCHIPEL Laboratory, University Tahri Mohamed Bechar, Algeria \\ ${ }^{3}$ Architect, temporary, Department of architecture, Faculty of technology, ARCHIPEL Laboratory, University Tahri Mohamed Bechar, \\ Algeria
}

Address For Correspondence:

RatibaWided BIARA, PHD, Responsible of Department of architecture, Faculty of technology, ARCHIPEL Laboratory, University Tahri Mohamed Bechar, Algeria

Email: townscape11@yahoo.fr

\section{ARTICLE INFO}

\section{Article history:}

Received 12 October 2017

Accepted 22 December 2017

Available online 31 December 2017

Keywords:

Oasis, dormitory town, landscape post

industrial, economy, resuscitation.

\begin{abstract}
A B S T R A C T
BACKGROUND: Bearer of identity signs, and traditional know-how, the vernacular establishment of the town of Kenadsa, is an admirable fact that responds to the needs of inhabitants. Crucible of perennial societal values, it is a messenger of the collective memory, and the expression of the federative feeling. The richness of this fabric is configured in the structural spontaneity of its micro space. Following the discovery of coal, this fabric passes to a largest mining city, where economic growth prospers, however, modes of production change and makes obsolete some traditional know-how. The loss of attractiveness has created at the heart of this city, a socially difficult situation. It gradually loses its specificities. Therefore, the dormitory town embodies the negative stereotype of a depressed post-industrial town. Whilst before, the city attracted a lot of people. Now it finds itself abandoned, giving little desire to wander. The postindustrial landscape reveals a sad aspect. This fact leads us to question about the appropriate action towards changing the face of the town to recover human and urban attractiveness.

OBJECTIVES: Restore the historical, spiritual, industrial and memorial characteristics of the city. Provide the city with welcoming structures through a veritable gateway that helps define the identity of a city. Inject along the main street activities capable of generating urbanity. To revive the artisanal activities, of which the city is praised. RESULTS: The development of the tourist attraction town of Kenadsa becomes a sine qua non, for a better appreciation of the picturesque landscape surrounding the city, and those intrinsic to the vernacular heritage, articulated with shifts in time to the industrial landscape. To do this, it should: adopt a physical regeneration: in case the dilapidated city unattractive, and a depressing place for residents to live there. Restore historical and Memorial of the city features.

CONCLUSION: Reading the landscape of the city, allows to highlight the flaws of the industrial landscape, to suggest a possible appropriation, to enroll in the sustainability and the quality of life of the citizens, ensuring an internal stimulation, for the creation of new jobs, ensuring the procrastination of the urban population.
\end{abstract}

Open Access Journal

Published BY AENSI Publication

(C) 2017 AENSI Publisher All rights reserved

This work is licensed under the Creative Commons Attribution International License (CC BY).

http://creativecommons.org/licenses/by/4.0/

\section{(c) (1) \\ Open Access}

To Cite This Article: RatibaWided BIARA, Adil MOSTADI, Sara Imane BIARA, The Scars of the Industrial Landscape of the City of Kénadsa. Aust. J. Basic \& Appl. Sci., 11(15): 64-70, 2017 


\section{INTRODUCTION}

At the gates of the Algerian Sahara, the city of Kenadsa, piggyback on the ramification of the ksour along the Saoura Wadi.

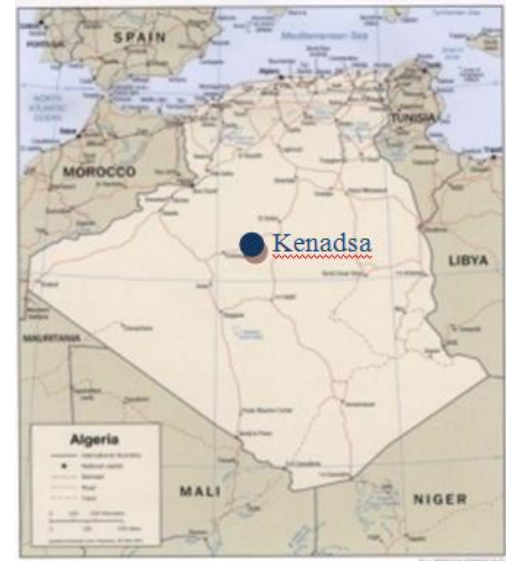

Fig. 1: map showing the situation of the city of kenadsa. Source ENCARTA. Microsoft

On the one hand, the ksourians acted at the extreme of their knowledge, and their means on a virtually blank space, to meet their needs. Their implementation has been formally dictated by the natural landscape in-situ: the Barga (Mountain double side), the Palm Grove, and the Wadi. In this landscape, the life of the ksourians were organized ensuring social cohesion and a friendly atmosphere.
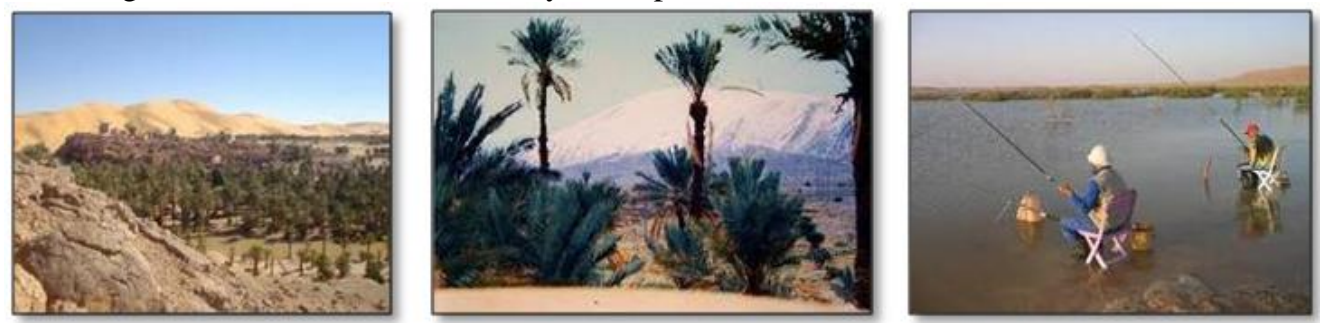

Fig. 2: natural landscape of Kenadsa. Source Author

On the other hand, a new city juxtaposed to the congregations of the past, as a result of industrial investments in mining activity. Instead of being as its equivalents pleasant to live, the city of Kenadsa, is inactive due to deindustrialization: people leave it early in the morning to work elsewhere, and in the evening on the way home, they do their shopping in their nearby workplaces.

Added to this, the quality of the physical space is deteriorated and the living environment is going downhill. This crisis lasts for years in the absence of any attempt to remedy. However, the city should be at the service of citizens: without the social factor and human values, architecture and urbanism, obviously, it would have no sense; in return, the latter must be a tool of social reintegration.

\section{Introduction - Review:}

The gloomy scenery of the Algerian cities is reflected as one of the signs of failure of the current architectural production. The buildings erect in all their ugliness next to each other without respecting the rules of art and urbanism. The same standard and charming architectural landscape is displayed here and there throughout all Algerian cities. Why does this casual attitude on the part of architects and decision-makers persist? Are we unable to shape a landscape in symbiosis with local values mainly because our old cities have a panoply of architectural elements that can serve as referents? This is the point that was raised by Mr. Merdji Samir in his magisterial 'Architectural metamorphosis of the Constantine cityscape': from the colonial city to the new city'. To tackle this issue, he undertakes his work on the basis of cumulative and reflexive approaches, including: observation, the examination of documents related to the subject, questioning method, objectivity, and reasoning.

As for Lilian Froger, in his article entitled "Industrial Landscape", he discusses the history of parks and industries in four regional natural parks: Lorraine, Montsd' Ardèche, Pilat and the Vercors Park. The interviews established in this work provide information on the discussions between the actors, in particular about the gaps that arise quickly between the demands of the inhabitants, or the former workers and the proposals of the artists who take part in the Industrial Landscape project. 


\section{Introduction - Materials:}

This work is built on a didactic approach to the landscape structured by four phases:
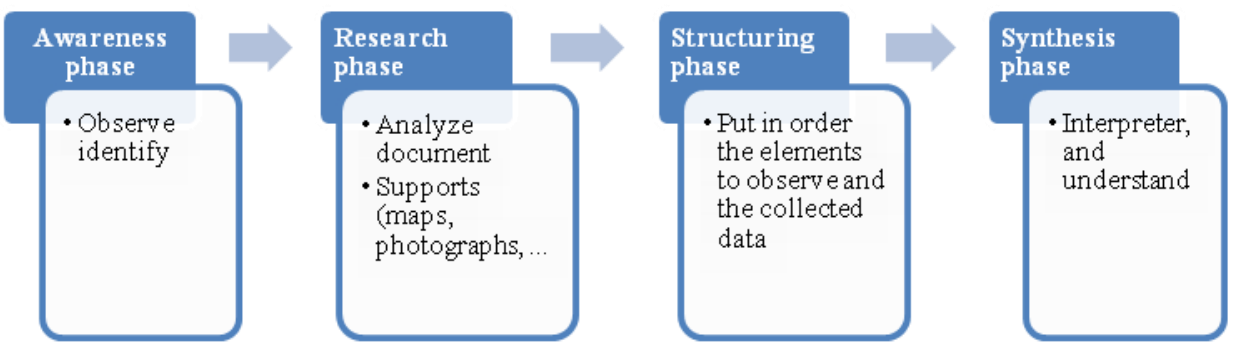

The entity of the landscape to Kenadsa:

Anthropogenic Scars in the Landscape of the city of Kenadsa:

The man tends to appropriate the places conferred on him by the nature by inserting its traces in the landscape which he modifies constantly by inserting his traces in the landscape. This is explained as follows: «The product of experimental knowledge is in the same way, the product of our performances and our action. The landscape is always the product of work, economy, there is no land that the human being has not at least partially explored or changed. "(Santi, 2003). Only once these transmutations were less noticeable, because they were less drastic. But today, the landscapes are clearly marked by human activity. This is the case in Kenadsa, where the form of ownership of the environment as a result of mining, had serious consequences on the city. Landscape radically shaped the scars in this space revealing signs, and disclosing the footprints of economic activity which the spirit rememorates due to vacant and abandoned industrial sites but staked by some Brownfields.
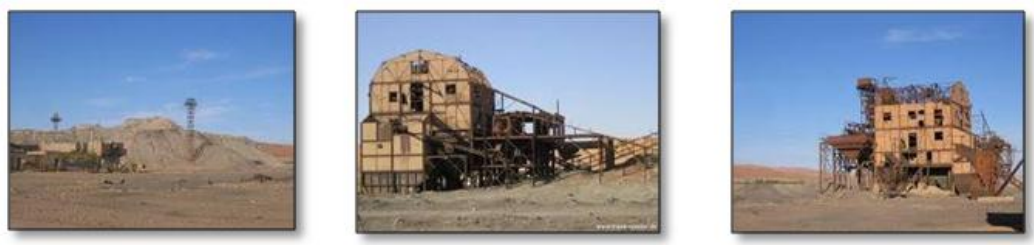

Fig. 3: scars of the industrialist landscape. Source Authors.

The cultivated landscape raises further concerns the desocialisation, urbanity, the quality of the physical space, and its mode of ownership. In fact, it leads to awareness of the fragility of this environment. «The landscape is inexhaustible in the sense that it offers a multitude of clues that tells us what it is, what it was and what it can become. Indeed, in the same flesh landscape prints and endures all the scars of the past. The landscape is a memory and I can ask it. »(Corajoud (dans) Dagonet, 1982).

\section{Landscape approach:}

Before even imagining a new reading to the question of stigmata enrolled in the landscape, it is important to grasp at first the concept of "landscape". The latter, is in fact, a complex reality, which is due to "its multiple use and not very rigorous". (Albert, 1976) and to the diversity of designs and approaches adopted to the same landscape by plural observers, architects, landscapers, artists, urban designers, or mere spectators.

Not only the landscape "is a construction and a human interpretation. (Santi, 2003), that is automatically linked to an observer (a person viewing). "If there is a reality that only exists through our eyes, it is the landscape, it is as stated by Leblanc as a look that is a kind of relationship of each man, of each society to its landscape." (Leblanc, 1993).

Given its polysemic and convoluted nature, landscape sees itself as an insurmountable notion. As a result, scientists reduce its practices on noticeable formal dimensions. Tacitly, the scope of intervention reduces and collaborates in margins of debates, as well as the problems of contemporary societies. Therefore, to restore a structuring scope to these fields, the landscape should be considered as virtue, as a framework of global interpretation, allowing subjects to merge circumspect plural, significant of a given context. Also, «evaluation of the territory, through the framework of the landscape, allows a player to qualify and make sense of a situation » (Fortin, 2005).

However, the landscape will become subjects of general interest, as if it gives rise to a public debate. Social acceptability is a first issue for the maintenance of the quality of the living environment. Thus, thanks to the professional advice of the space, added to the look that everyone will focus on the place, will grant the recognition of a sense and assigning a value to it, subsequently, there will emerge the "creation of a new landscape. (Alain Roger in Marcel, 1989). 
How to understand a landscape and build the same reality differs from one actor to another, that it is: artist, landscape architect or architect. However, their first concern is to understand the landscape, to master, and of aestheticizing it at intervention through in exordium. "Not admissible in the absence of a "contemporary aesthetic of abandonment" which would consider the "ruins of modernity" other than a disaster. (Jeudy, 2001, cité par Paquette, 2008).

In other words, to change our perception of the landscape, in now the memory of the place: «I look at the landscape through an archetype of representation that produces this landscape as such, which allows me to understand it. But conversely, this archetype was itself used to build this landscape» (Berque dans Marcel, 1989).

\section{Results:}

\section{The industrial past, and intentions for its future:}

The idea is to revitalize and give new life to this "inert," city, to give a different reading of this imperishable scar in the landscape, to suggest a harmonious dialogue between the industrial past, and the future of this site rich in user-friendly landscape, and especially to create social links while improving the living conditions of the inhabitants. The atmosphere, the vitality and dynamism are all elements that make you want to live, share, and develop a territory.

In addition, the purpose is not to hide the industrial era which marked this landscape, but rather to become aware of its history, and to take a positive look, or even legendary on it. Because even if these sites appear sometimes troublesome, they still hide their beauty, just have the courage to accept these landscapes shaped by man and industry, according to the French philosopher Odile Marcel« [...] We can deplore the course of the world or want to influence it. Man is the master of his choice. He must have the courage of its culture and its artifices ...» (Marcel, 1989).

In this context, the challenge, is to make the industrial landscape, an incentive to exploration, and conversion of these sites for new uses. This approach is intended to «make aesthetic relationships between human and machine... ». and «remove all disturbing otherness» attached to the landscape (Sansot cité par Paquet, 2009). Circumstances of these landscapes require a broad understanding and a deep reflection.

Beyond the restoration of these landscapes, it is relevant to preserve the cultural context, the natural environment and local traditions, to find the place for sharing both identity and emotion. These are the conditions that can take place only by placing people at the heart of the process on the one hand, to meet the diversity of needs and choices of life of the inhabitants; and by involving the commitment of managers on the other hand (the political will, a key success factor).

In addition, the conservation of historic districts and cities must be effective and part of a coherent policy of economic and social development. It should also be taken into account in the plans of development and planning at all levels. «Now, the backup plan must seek to define a harmonious articulation of historic neighborhoods throughout the city. » International Charter of ICOMOS for the preservation of historic cities (1987).

Overall, revitalizing, is therefore, acquiring a certain balance between the needs of the citizens, economic and cultural development, the preservation of heritage, and finally the development of the landscape of the city. «Social cohesion and economic competitiveness are not mutually exclusive objectives but, in fact, complementary objectives. In order to achieve a balance between these two aspects, governance is the key element. It should develop a strategic vision that takes account of each municipality and reconciles the various objectives of these different actors». (Kamal-Chaoui, 2005)

\section{Respect for the spirit of the place:}

After Odile Marcel landscapes reproducing the image of our reality: «they are both ancient and modern and together of many passes and various gifts» (Marcel Dagonet, 1982). In the same context, barrel, David Lowenthal adds that the past, must be inspired to be noticeable in our contemporary landscapes. «Most of the architecture design their work as historically accurate, but give him a modern spirit. » (Lowenthal, 2008).

Indeed, perpetuating the symptomatic intrinsic to the site, implies taking into account "the spirit of the place." as Norberg-Schulz calls it among other things, a kind of synthesis of the material (items visible and measurable, but with their links with some human actions such as ownership), et de immaterial (referral to memory regarding subjective perceptions). If, however, these two concepts interact, it is simply the fact that one generates the other. "The mind built the place and at the same time, place invests and structure the spirit" (Turgeon, 2009). Besides, for this author, the forms of intervention that respect the spirit of the place are the only ones capable of succeeding. "The identity of the man assumes the identity of the space» (Norberg-Schulz, 1993). 


\section{Prospects for the revitalization:}

Expectation of vegetable urbanism in the post-industrial city landscape:

Since the 19th century, in the large industrial cities of England, landscape models have sought to unravel the adverse effects of urbanization which focuses the human masses in a brutal way: nature is seen by pioneers like cure for urban ills.

As the movement of urban expansion extended progressively, a phase of tissue sanitation was opened, as evidenced by the Paris Haussmann, and in which programs provide the Green facilities City: parks, gardens, boulevard with, green belts, ...With time offsets, the planning of urban expansion arises, with the direct integration of nature, whence the appeal to urban planners and landscapers becomes a reality.

Furthermore, the standardization of post-industrial urban areas, as well as the degradation of their environmental components, give birth to a policy known as "sustainable development." and the birth of a new discipline so designated by urban ecology, treating then, in addition to problems related to energy or pollution, and the management of the devalued industrial or residential space.

The craze to the natural factor in the post-industrial city, covers new practices designated by: plant, hybrid urbanism of horticulture, landscaping and landscape architecture. The latter takes more challenges, to provide answers to the environmental stress to which the present town, is subject as well as to demand unprecedented of green spaces; in this case to a friendly urban development, or a better be physiological. from Habermas, «the resurgence of plant landscape in the city also meets a need for stability and durability., in workaround of the functionalist upheavals that have made this a transient and changing place». (From Habermas, in Mario Bédard, Jacques Béthemont, Guy Mercier, 1998)

Accordingly, the landscape quality in urban areas is more to be considered as a valuable asset, now, it sets itself to adopt a global vision that makes that Visual quality interpreting a State of equilibrium ensuring viable development in the urban areas only, «it's not as far to maintain or reintroduce the traditional landscape, but to design a new type characterized by the social use of spaces Greens. more and more in demand». (Franco Migliorini, in Mario Bédard, Jacques Béthemont, Guy Mercier, 1998). This is an illustration of a new aesthetic, managed by the order and variety, and challenged the simple visual satisfaction with the usefulness and beauty. (Planners and landscapers competed favorably to the proliferation of new life management taking into consideration positivism and romanticism)

\section{The land art:}

Land Art, this artistic practice in accordance with the natural environment, is the reanimation of the industrial city working with landscape (an art form that nature is tool of expression). The landscape will become so reshaped, following the intervention of the artist on the components of it. By adopting various approaches, the land artist manipulates «of strictly architectural factors such as weighing and elevation, size and scale. » (Tiberghien, 2001). Here few approaches are described in this respect.

Walter De Maria and Richard Long formulate their arts on the site superficially.

- Michael Heizer and Robert Smithson speak in-depth and sensitive to the environment in Situ. Michael Heizer seizes the site depending on his art, he took advantage of the place in revealing and rewarding its qualities. using components: scales, material, relief and geography: "if the work is understood through its site, the site, inversely, is understood through the work, and takes on new meaning » (Tiberghien, 1993).

- Robert Smithson, the forerunner of Land Art, has further developed his art, where the landscape testifies to an industrial past age. It offers art to act as mediator, reconciling between ecology and industry. The art of the latter is considered by package as being social more than aesthetics.

- Others do not disguise the nature of the place, they make commemorative items, the project reveals a museum space where the spectator is a relevant role for example.

\section{Discussion:}

\section{If tourism revived the city:}

The development of town of Kenadsa at the level of touristic attraction, becomes a sine qua non, for a better appreciation of the picturesque landscape surrounding the city, and those intrinsic to the vernacular heritage, articulated with shifts in time to the industrial landscape.
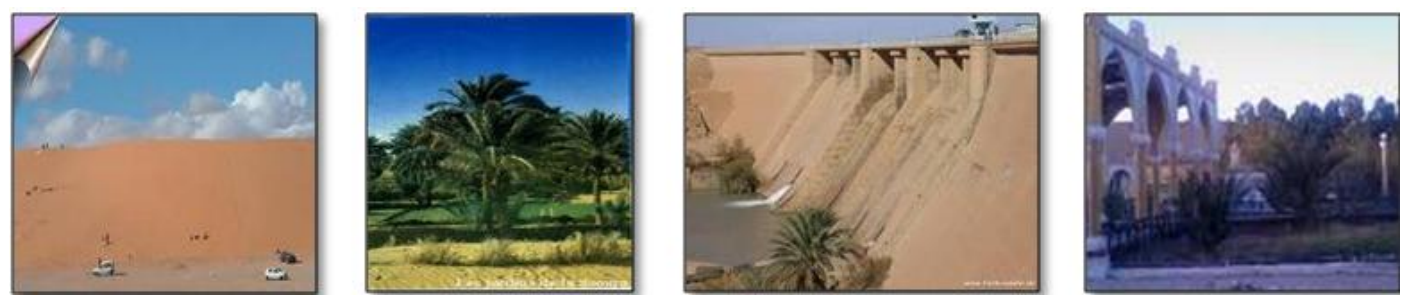

Fig. 4: some tourist places in Kenadsa 
To do this, it would be necessary: adopt a physical regeneration: in case of a dilapidated city without unattraction, and a depressing place for residents to live there. Restore the historical and Memorial of the city features.

- Provide the city in childcare facilities.

- Inject along the main street structures and activities able to generate urbanity.

- Shape of fold-out walks along natural landscapes, outskirts of the city.

- $\quad$ Resurrect the craft activities, of which the city prides itself
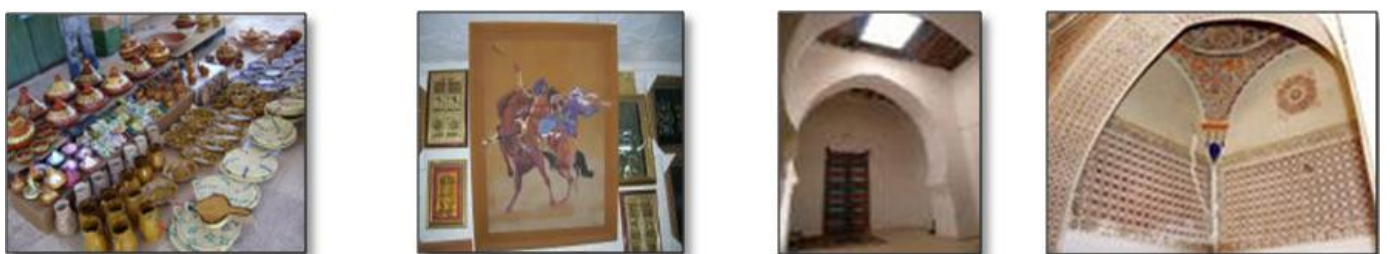

Fig. 5: craft samples in Kenadsa

\section{When the festivity reveals the dynamics of the city:}

In addition to its posture, the popular party at the official ceremonies, had long showed that it is a tool to make the city of Kenadsa, and to exercise a power of seduction. Therefore, it gives the city in grassland social, to find a place of recurring appointment. In this sense the ambitious current policies of renewal and animation in industrial contexts, rely on partying, or culture in general.

If the party represents a fleeting moment in the history of urban transformation, the regular festivals show a lot of success in the social landscape. As elsewhere in the world, this cultural event testified with success of social and educational projects, a kind of cultural regeneration that promotes urban and environmental regeneration.

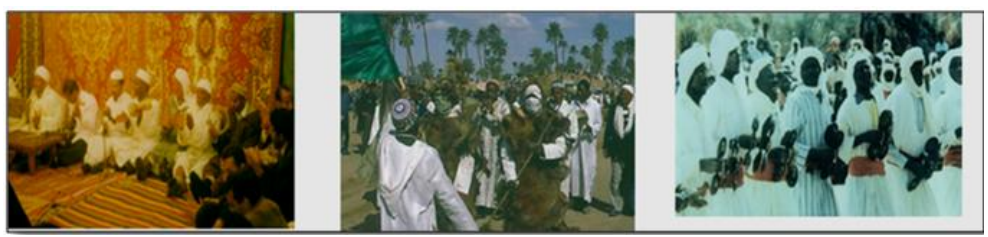

Fig. 6: types of cultural events in Kenadsa

\section{Conclusion:}

Many questions arise our perception of the city. The practices and usages should change to overcome this bad situation in order to enroll in the sustainability and the quality of the citizens' life, ensuring an internal stimulation, for the creation of new jobs and the procrastination of the urban population.

\section{Among the strategies likely to achieve this goal:}

- The necessity to take into account a set of customs, behavior, attitudes, needs, and organized feelings, that help to the adherence of human dimensions to both common benchmarks and memory. It notably allows access to the right to the city, the acquisition of the sense of belonging and identity recognition. Thus, understanding the living environment, promotes a place of urbanity, a place for sharing identity and emotion.

\section{Recommendation:}

- Adopt for revitalization, but one that meets the physical and cultural needs of citizens, since this is the rule of the human dimension of the rule of the cultural dimension of the living environment. The revitalization has intended to give life, to ensure the conditions of existence. Give life because there is danger: danger of misunderstandings, ambiguities, exclusions and in this case the risk of any community memory.

- The spatial data not allowing itself to appreciate the built the spatial data not allowing itself to appreciate the built, then combine spatial cohesion in the city, by involving citizens in the decision-making process. But before, the public must be educated in architecture, and environment. "The city of the future cannot be built only by specialists but with and by the inhabitants themselves. In the 21 st century, the city must be the place where create and manage social transformations. The challenge is to humanize the cities so that the urban quality that they promote and create contribute to enhance citizenship and interculturality, making them there even more 
civil" the challenge is to humanize the cities so that the urban quality that they promote and create contribute to enhance citizenship and interculturality, making them there even more "civil" (Céline Sachs-Jeantet, 1996)

- Redirect action, to support the negotiated city, the project is being built by its communication.

- Develop cultural activity, which represents in the contemporary social structures, a way to vitality community, determining the attractiveness of cities.

- The exercise that is to perpetuate the social landscape is to transmit, and continually reinterpret our cultural heritage. In this exercise, it is relevant to take into account the constantly changing the social factor, and the technology; but remember that the survival of the historical framework can pass, by keeping up the inhabitants, and craft activities inherent to the city.

- Revitalize traditional trades, opening the perspective of renewal by creating. It is covered by this, the promotion of local products, the economic development, as well as the proliferation of creation destined to tourism.

- Develop services and facilities, and public spaces.

- Intervene in the requalification operations through most castings.

- Consolidate the tourist destination of the city.

\section{REFERENCES}

Albert, G., 1976. Paysages et pertinence architecturale, Genèvres, C.R.A.A.L

Charte internationale de l'ICOMOS pour la sauvegarde des villes historiques, 1987.

Dagonet, F., 1982. Mort du paysage ? : Philosophie et esthétique du paysage, France, Collection Mileux.

Fortin.M. J., 2005. Paysage industriel, lieu de médiation sociale et enjeu de développement durable et de justice environnementale : les cas des complexes d'Alcan et de Péchiney, thèse de doctorat, université du Québec.

Kamal-Chaoui, L., 2005. Directeur de la gouvernance publique et du développement du territoire (OCDE), Débat Politiques urbaines et le droit à la ville, UNESCO, Paris

Leblanc, L., 1993. Paysages, Paris, Le Moniteur.

Lowenthal, D., 2008. Passage du temps sur le paysage, Suisse, Infolio.

Marcel, O., 1989. Composer le paysage : constructions et crises de l'espace (1789-1992), France, Éditions Champs Vallon, pp : 221-292.

Mario Bédard, J., and G. Béthemont, 1998. La ville en quête de nature Cartier, les éditions du Septentrion, Québec, pp: 201-213.

Norberg-Schulz, Ch., 1997. L'art du lieu : architecture et paysage : permanence et mutations, Paris, Le moniteur.

Paquet, S., 2009. Le paysage façonné : les territoires postindustriels, l'art et l'usage, Quebec, Presses de l'Université Laval.

Sachs-Jeantet, C., 1996. Humaniser la ville, UNESCO, Istanbul Forum HABITAT II

Santi, S., 2003. Le paysage et la question du regard, France, Malissard, pp: 39-78.

Tiberghien, G., 2001. Nature, art, paysage. France, Acte Sud, pp: 94-141.

Turgeon, L., 2009. L'esprit du lieu : entre le patrimoine matériel et immatériel, Québec, Presses de l’Université Laval, L.III. 